\title{
DAMPAK PSIKOLOGI NOVEL SANG ALKEMIS \\ KARYA PAULO COELHO TERHADAP PEMBACA
}

\author{
Machrus Abadi \\ machrus_abadi@u.ac.id \\ Jamila Wijayanti \\ jamilawijayanti@ub.ac.id \\ Universitas Brawijaya
}

\begin{abstract}
Abstrak: gagasan-gagasan resepsi psikologi dalam karya sastra menunjukkan betapa pentingnya efek sastra bagi pembaca. Sastra memiliki daya keras dan lunak dalam kehidupan psikologi pembaca. Sebagai daya keras, sastra akan mampu mengubah kehidupan pembaca secara langsung dan cepat seperti sakit hati, marah, berteriak keras setelah membaca sastra. Sebagai daya lunak, sastra akan merambat pelan-pelan ke dataran psikis pembaca. Dalam proses ini bukan mustahil jika pembaca suatu saat akan berubah kiblat hidupnya. Novel Sang Alkemis karya Paulo Coelho ini merupakan dongeng spiritual tentang bagaimana merealisasikan mimpi untuk menjadi kenyataan. Novel ini mampu memberikan motivasi dan inspirasi terhadap pembaca untuk tergerak meraih cita-citanya. Tujuan penulisan ini adalah untuk mengungkapkan dampak-dampak psikologis karya sastra terhadap karakter, pendidikan, spiritualitas, dan kaitan karya sastra sebagai media motivasi dan inspirasi dalam pendidikan.
\end{abstract}

\section{Kata kunci: Psikologi sastra, Sang Alkemis, Paulo Coelho}

\section{Pendahuluan}

Tulisan ini mengkaji dampak psikologi novel Sang Alkemis karya Paulo Coelho terhadap pembaca sebagaimana sub judul yang tertulis dalam novel tersebut yang menyebutkan bahwa Sang Alkemis merupakan dongeng spiritual tentang realisasi mimpi Anda. Jelaslah bahwa Sang Alkemis ditulis dengan tujuan memberikan motivasi dan inspirasi terhadap pembaca. Terkait dengan psikologi sastra bahwasannya tujuan psikologi sastra adalah memahami aspek-aspek kejiwaan yang terkandung dalam karya sastra. Ada tiga cara yang dapat dilakukan untuk memahami hubungan antara psikologi sastra dengan karya sastra, yaitu: (a) memahami unsur-unsur kejiwaan pengarang sebagai penulis, 
(b) memahami unsur-unsur kejiwaan tokoh-tokoh fiksional dalam karya sastra, dan (c) memahami unsurunsur kejiwaan pembaca (Ratna, 2012:342-343). Tulisan ini di dalamnya lebih memfokuskan pada psikologi pembaca, yaitu latar belakang psikologi pembaca dan aktivitas kejiwaan pembaca dalam mengapresisasi karya sastra (Siswanto dan Roekhan, 2015:117). Aktivitas kajiwaan ini meliputi dampak psikologis karya sastra terhadap karakter, pendidikan, dan spiritualitas. Selanjutnya dipaparkan mengenai kaitan antara karya sastra dengan pendidikan, yaitu karya sastra dapat digunakan sebagai media motivasi dan inspirasi.

Novel Sang Alkemis yang digambarkanmelalui tokoh dan alur cerita tersebut dapat mempengaruhi emosional pembaca. Pembaca memperoleh inspirasi untuk mewujudkan mimpi dan mengikhtiarkan takdirnya dalam perjalanan hidup ini. Selain itu, melalui pembacaan novel ini dapat merangsang kapasitas kita untuk bermimpi, hasrat kita untuk mencari, dan menemukan diri sendiri melalui pencarian jati diri. Hal ini tidak dapat terlepas dari kenyataan yang membuktikan bahwa sastra memiliki pengaruh terhadap pembaca, yakni pengaruh emosional. Istilah-istilah emosi atau istilah-istilah lain yang mengatakan hal-hal yang sama dengan emosi, seperti kesenangan, kegembiraan, ketampanan, kemulusan atau inspirasi, merupakan hal-hal yang diungkapkan dalam karya sastra (Endraswara, 2008:4142).

Kesusastraan mempunyai efekefek yang kompleks seperti aspek yang terdapat pada kepribadian manusia sebagaimana kita ketahui. Kesusastraan dapat menggerakkan kita ke arah dunia imipian dan dunia fantasi yang indah dan menentramkan. Kenyataan tersebut membuktikan bahwa anggapan yang mengatakan bahwa karya sastra tidak bermanfaat untuk kehidupan praktis di dunia, ternyata tidak sepenuhnya benar (Endraswara, 2008:42-3). Berkait dengan kepribadian tokoh yang terepresentasi melalui tokoh Santiago dalam novel Sang Alkemis, dapat memberikan pengaruh yang luar biasa terhadap pembaca dalam memotivasi untuk menggapai mimpimimpi yang hendak dicapai. Melalui 
bahasa sederhana yang ditulis Paulo Coelho dapat menggerakkan jiwa pembaca untuk bermimpi, berusaha meraih mimpi, jiwa pantang menyerah dan memahami hakikat hidup dalam dunia.

\section{Paulo Coelho dan Sang Alkemis}

Sang Alkemis merupakan karya klasik modern yang ditulis oleh salah satu dari limabelas pengarang terbesar sepanjang sejarah yakni sastrawan Brazil Paulo Coelho. Paulo Coelho adalah novelis kelahiran Rio de Janeiro, Brazil yang menjalani kehidupan yang sangat kompleks. Ia pernah di penjara karena terlibat kelompok yang menentang pemerintahan diktator di Brazil. Ia memiliki keyakinan kuat untuk mewujudkan impiannya, yaitu menjadi seorang penulis.Meskipun ia bekerja di berbagai bidang, tapi hanya dengan menulislah ia dapat mengekspresikan dirinya. Novelnovelnya selalu berceritakan tentang kehidupan manusia yang terjebak diantara yang boleh dan tidak boleh dilakukan. Namun dengan gaya bahasanya yang sederhana, ia sanggup menghadirkan cerita yangtidak berkesan menggurui dan seringkali memberikan perspektif baru pada cara pandang seseorang terhadap suatu hal. Beberapa novelnya yang sudah dipublikasikan adalah, The Pilgrimage, The Alchemist, Warrior of The Light, By the River Piedra I Sat Down and Wept, The Devil and Miss Prym, The Valkyries, Veronika Decided to Die, The Fifth Mountain, The Zahir, The Witch of Portobelo,dan yang paling terbaru adalah The Winner Stand Alone(Wulan, 2010:4).

Novel Sang Alkemis ini bercerita tentang perjalanan seorang bocah bernama Santiago, gembala Andalusia yang mengembara mencari harta duniawinya. Diawali dengan sekelumit prolog tentang Narcicus dan Sang Danau, kemudian cerita dialihkan pada Santiago yang berusaha menggapai mimpinya. Bocah gembala ini bermimpi tentang harta karun yang ada di Piramida Mesir. Ia bermimpi yang sama dua kali dalam tidurnya, dan hal tersebut membawanyamemasuki dunia baru yang tidak pernah ia pikirkan sebelumnya. Dari kampungnya di Spanyol, ia ke Tangier dan menyeberangi gurun Mesir. Di oasis 
ia mengalami perjumpaan yang menentukan dengan sang alkemis. Ia juga bertemu dengan gadis gurun yang menjadi kekasih sejatinya. Fatima.

Santiago dalam perjalanan mencari harta karun harus belajar memahami pertanda, dan juga mendengarkan hatinya. Pada tahap inilah Coelho meletakkan berbagai macam simbol untuk membentuk ceritanya. Ia memperkenalkan konsep alkemi yang sarat simbol sebagai media untuk menyampaikan pikirannya atas apa yang seharusnya manusia lakukan dalam hidup. Ia menghadirkan 11 simbol utama yang sering kali muncul dalam setiap penceritaan dalam novel tersebut. Simbol-simbol ini membantu perkembangan kepribadian Santiago yang lugu sehingga berubah menjadi lebih bijaksana dan mengerti akan kehidupan. Perjalanan Santiago mengajar kita tentang kearifan esensial, yaitu bagaimana mendengar hati kita, belajar membaca pertanda yang bertebaran di sepanjang hidup manusia. Dan, terutama bagaimana mengikuti mimpi-mimpi kita.
Pengkajian ini menitikberatkan pada psikologi pembaca yaitu dampak psikologis karya sastra terhadap karakter, pendidikan, spiritualitas, dan kaitan antara karya sastra dengan pendidikan yang dapat digunakan sebagai media pembelajaran yang memotivasi dan menginspirasi. Sebagaimana menurut pendapat Endraswara (2008:155) yang menyatakan bahwa sastra dalam konteks pembaca akan berpengaruh cepat dan lambat. Pengaruh cepat merupakan daya keras, spektakuler, dan menantang sehingga pembaca spontan berubah sikap dan wataknya. Mungkin pula pembaca akan menirukan gerakangerakan, siulan-siulan, dan modelmodel yang ditawarkan dalam sastra. Sebaliknya, sastra juga dapat secara lambat menyerukan daya tertentu, tetapi tetap pasti. Meskipun daya serap pembaca lunak, lembut namun tetap berpengaruh dan sastra semacam ini sering sulit hilang (nabet).

\section{Dampak Psikologi Karya Sastra Terhadap Karakter}

Menurut pendapat Marahimin (dalam Wahyudi dan Roekhan, 
2015:124), dampak psikologis karya sastra terhadap karakter pembacanya pernah dilakukan oleh McCelland, seorang psikolog sosial yang tertarik pada masalah-masalah pembangunan.

McCelland memperbandingkan bangsa Inggris dan Spanyol yang pada abat ke-16 merupakan dua negara raksasa yang kaya raya, namun sejak itu Inggris terus berkembang menjadi makin besar, sedangkan spanyol menurun menjadi negara yang lemah. Hal ini disebabkan karena dongeng dan cerita anak-anak di Inggris pada awal abad ke-16 itu mengandung semacam 'virus' yang menyebabkan pendengar atau pembacanya terjangkiti penyakit butuh berprestasi, the need for achievement, yang kemudian disimbolkan dengan ' $\mathrm{n}$-Ach', yang menjadi sangat terkenal. Sedangkan cerita anak dan dongeng yang di Spanyol justru meninabobokkan, tidak mengandung 'visrus' tersebut.

Novel Sang Alkemis terkait dengan dampak psikologi karya sastra terhadap karakter adalah bahwa novel ini mampu menebarkan 'virus' the need for achievement. Novel ini menggerakkan pembaca untuk berani bermimpi dan berusaha meraih mimpinya. Novel ini meyakinkan bahwa setiap orang berhak untuk memiliki cita-cita dan mewujudkan cita-citanya.

"Kamu datang supaya kamu dapat memahami mimpimimpimu," kata perempuan tua itu. "Dan mimpi adalah bahasa Tuhan. Ketika dia berbicara dengan bahasa kita, aku dapat menafsirkan apa yang dikatakanNya. Tapi bila dia bicara dengan bahasa jiwa, Cuma kamu yang bisa mengerti. Tapi, bahasa apapun itu, aku meminta bayaran untuk konsultasi ini”. (halaman 15)

Menurut pendapat Milner (dalam Minderop, 2016:19), Freud dalam sebuah pembahasan menyatakan bahwa mimpi merupakan gambaran ambisi untuk mencapai sesuatu dalam hidup. Freud juga percaya bahwa mimpi dapat mempengaruhi perilaku seseorang. Mimpi merupakan representasi dari konflik dan ketegangan dalam kehidupan seharihari (Eagleton, 1996:437). Demikian hebatnya derita karena konflik ketegangan yang dialami sehingga sulit diredakan melalui alam sadar. Mimpi kerap tampil dalam bentuk simbolisasi dan penyamaran sehingga membutuhkan analisis 
mendalam untuk memahaminya (Minderop, 2016:17-18).

Novel Sang Alkemis bercerita tentang Tokoh Santiago yang bermimpi jika dia mau mendatangi piramida, dia akan menemukan harta terpendam. Mimpi yang sama menghampiri Santiago dua kali dalam tidurnya. Mimpi ini merupakan gambaran ambisi Santiago untuk mengubah jalan hidupnya dari seorang penggembala Andalusia untuk mencari harta duniawinya. 'Virus' yang disampaikan dalam novel ini adalah bahwa semangat bekerja keras dan pantang menyerah adalah kunci utama dalam meraih mimpi. 'Virus' the need for achievement yang terejawantahkan dalam sikap semangat bekerja keras dan pantang menyerah inilah yang diharapkan dapat mempengaruhi dan menggerakkan pembaca untuk memewujudkan legenda pribadi masing-masing.

"Legenda pribadi adalah apa yang selalu kita ingin kita tunaikan. Setiap orang, saat mereka belia, tahu apa legenda pribadi ."

"Pada titik kehidupan mereka itulah semuanya jelas dan segalanya mungkin terjadi. Mereka tidak takut untuk bermimpi, dan mendambakan segala yang mereka inginkan terwujud dalam hidup mereka. Tapi, dengan berlalunya waktu, suatu daya misterius mulai meyakinkan mereka bahwa mustahillah bagi mereka untuk mewujudkan legenda pribadi mereka." (halaman 24)

Setiap manusia pada dasarnya mengetahui apa yang menjadi legenda pribadinya. Namun, tidak semua orang percaya diri untuk mencoba mewujudkannya. Sebagian besar mengubur mimpinya karena merasa takut dan merasa tidak mampu menggapainya. Novel ini memberikan penyadaran terhadap pembaca bahwasannya misi manusia di dunia adalah mewujudkan legenda pribadi yang bersumber dalam jiwa alam semesta.

"Itu adalah kekuatan yang tampaknya negatif, tapi sebenarnya menunjukkan kepadamu cara mewujudkan legenda pribadimu. Kekuatan ini mempersiapkan rohmu dan kehendakmu, karena ada suatu kebenaran terbesar di planet ini: siapapun kamu, atau apapun yang kau lakukan, saat kau benar-benar menginginkan sesuatu, itu karena hasrat tadi bersumber di dalam jiwa alam semesta. Itulah misimu di dunia" (halaman 25) 
Dampak Psikologis Karya Sastra Terhadap Pendidikan

Melalui pembacaan sebuah novel, kita dapat belajar bahwa pendidikan tidak hanya soal nilai. Pendidikan lebih pada pembentukan karakter siswa. Karakter tidak hanya dibangun dari kecerdasan intelektual saja, melainkan dari seluruh kecerdasan siswa. Seluruh kecerdasan inilah yang disebut multiple inteligence atau kecerdasan ganda (Siswanto dan Roekhan, 2015:127). Multiple inteligence merujuk pada tujuh komponen kecerdasan manusia yang meliputi kecerdasan (1) linguistik-verbal, (2) matematika-logis, (3) visual-spasial, (4) ritmik-musikal, (5) kinestetik, (6) interpersonal, dan (7) intrapersonal.

Intelegensi interpersonal sangat berhubungan dengan kemampuan untuk memahami orang lain. Howard Gardner (dalam Ula, 2013:96) menjelaskan bahwa intelegensi personal merupakan kemampuan untuk mengerti dan peka terhadap perasaan, watak, perangai, intensi, motivasi dan temperamen orang lain. Singkatnya, intelegensi personal merupakan kemampuan untuk memahami dan bekerja sama dengan orang lain. Intelegensi jenis ini menuntut kemampuan untuk menyerap dan tanggap terhadap suasana hati, perangai, niat, dan hasrat orang lain.

Dalam novel Sang Alkemis, kecerdasan intelegensi intepersonal ditunjukkan dengan kemampuan gadis gurun, Fatima, yang menjadi cinta sejati Santiago dalam memahami apa yang menjadi citacita Santiago. Tokoh Fatima memberikan dukungan kepada santiago dalam meraih mimpinya. Fatima mampu meyakinkan Santiago bahwa cinta sejati tidak menghalangi seseorang untuk mewujudkan legenda pribadinya. Hal ini memberikan penyadaran terhadap pembaca bahwa mencintai seseorang tidak harus mengekang seseorang untuk berbuat sesuatu sesuai dengan keinginan kita. Mencintai berarti memberikan kesempatan kepada orang lain untuk berjuang meraih mimpi-mimpinya.

$\begin{array}{lr}\text { "Kamu } & \text { telah } \\ \text { menceritakan } & \text { mimpi- } \\ \text { mimpimu, tentang raja tua dan } \\ \text { hartamu. Dan kamu telah } \\ \text { memberitahuku r tentang } \\ \text { pertanda. Jadi sekarang, aku }\end{array}$


tidak takut apapun, karena pertanda itulah yang telah membawa dirimu kepadaku. Dan aku adalah bagian dari mimpimu, bagian dari legenda pribadimu, seperti hartamu."

Itulah sebabnya aku ingin terus menuju cita-citamu. Bila kamu harus menunggu sampai perang selesai, tunggulah. Tapi bila kamu harus pergi sebelumnya, teruskan pencarian mimpimu. Bukit bukit pasir berubah oleh angin, tapi gurun tak pernah berubah. Begitulah yang akan terjadi dengan cinta kita. (halaman 104)

Selain kemampuan intelegensi interpersonal, yang tidak kalah menarik adalah kemampuan intelensi intrapersonal yang dimiliki oleh tokoh Santiago dalam novel Sang Alkemis. Tanpa memiliki kemampuan intrapersonal yang bagus mustahil kiranya tokoh Santiago mampu meraih mimpinya. Perjalanan tokoh Santiago dalam mewujudkan mimpinya terkadang menuntutnya untuk mengambil keputusan-keputusan berat dalam hidupnya, mengendalikan perasaannya, dan kemampuan memotivasi diri sendiri ketika tokoh Santiago merasa kalah atau gagal untuk mencoba bangkit dari keterpurukan sehingga dia mampu melakukan sesuatu yang lebih berguna.

"Itulah prinsip yang mengatur semua hal," katanya. "Dalam alkemi, itu disebut jiwa buana. Bila kamu menginginkan sesuatu dengan segenap hatimu, itulah saat terdekatmu dengan jiwa buana. Ia selalu merupakan kekuatan yang positif"

"segala yang ada di dunia berubah tanpa henti, karena bumi ini hidup dan mempunyai jiwa. Kita adalah bagian dari jiwa itu, maka kita jarang menyadari bahwa ia bekerja untuk kita. Tapi di toko kristal itu kamu mungkin menyadari bahwa gelas-gelas pun bekerja sama dalam suksesmu." (halaman 84)

Kutipan di atas memberikan penyadaran terhadap pembaca bahwa setiap apa yang ada di dalam bumi ini memiliki jiwa buana. Jiwa buana merupakan kekuatan positif yang ada dalam setiap makhluk. Ketika kita menginginkan sesuatu dengan segenap hati, maka pada saat itulah jiwa buana menjadi dekat dengan kita. Ketika kita berbicara dengan hati dan perasaan, tentu hal ini tidak akan terlepas dari kemampuan seseorang dalam intelegensi intrapersonalnya. Bagaimana 
seseorang mampu memahami diri sendiri dan dapat melakukan yang terbaik untuk dirinya. Hal ini sebagaimana dijelaskan bahwa intelegensi intrapersonal atau intelegensi intrapribadi adalah kecerdasan dalam diri sendiri. kecerdasan dan kemampuan untuk mengerti diri sendiri, apa yang terbaik yang harus dilakukan, apa yang harus dihindari serta apa saja yang dapat meningkatkan kemampuan diri. Jenis kecerdasan ini teediri dari kemampuan untuk mengenali emosi diri, (mengenali perasaan sendiri sewaktu perasaan atau emosi sedang naik), kemampuan mengelola emosi (kemampuan untuk mengendalikan perasaan sehingga tidak meledak-ledak dan akhirnya dapat mempengaruhi perilaku yang salah), kemampuan memotivasi diri (kemampuan untuk memberi semangat pada diri sendiri agar dapat melakukan sesuatu yang baik dan bermanfaat) (Ula, 2013:97)

"Jangan pernah berhenti bermimpi," raja tua itu pernah berkata. "Ikutilah pertanda." "Jika kamu menginginkan sesuatu, segenap alam semesta akan membantumu mencapainya," kata raja tua itu. (halaman 67)
"Yang masih pelu kau ketahui adalah: sebelum sebuah mimpi terwujud, jiwa buana menguji semua yang telah dipelajari di sepanjang perjalanan. Ia melakukan hal ini bukan karena ia jahat, tapi supaya kita mampu-sebagai tambahan untuk mewujudkan mimpi-mimpi kita - menguasai pelajaran-pelajaran yang kita tekuni saat kita bergerak menuju mimpi itu. Itulah titik saat kebanyakan orang menyerah. Itulah titik saat, seperti yang kami ucapkan dalam bahasa gurun, orang mati kehausan ketika pohonpohon palem sudah terlihat di cakrawala." (halaman 142)

Dalam perjalanan meraih mimpi, kutipan di atas merupakan kekuatan yang dapat mememberikan motivasi terhadap diri tokoh Santiago. Semangat pantang menyerah karena tidak mau sia-sia dalam menjalankan misi di dunia. Santiago memiliki cara tersendiri untuk mempercayai kekuatan yang ada pada dirinya bahwa dia mampu dan dia bisa menggapai apa yang dia inginkan. Santiago meyakini bahwa gagal berjuang meraih mimpi itu lebih baik daripada orang yang tidak memiliki mimpi untuk diperjuangkan.

"Tapi bagaimana kalau aku tidak bisa?" 
"Maka kau akan mati di tengah-tengah perjuangan mewujudkan legenda pribadimu. Itu masih jauh lebih baik daripada mati seperti berjuta-juta orang lainnya, yang bahkan tidak tahu apakah legenda pribadi mereka. Tapi jangan khawatir,... biasanya ancaman kematian membuat orang jauh lebih menyadari jiwa mereka" (halaman 152)

\section{Dampak Karya Sastra Terhadap}

\section{Spiritualitas}

Karya sastra dapat digunakan untuk mengembangkan etika dan nilai. Nilai yang diajarkan dapat berupa nilai spiritual. Secara terminologi, kecerdasan spiritual merupakan kecerdasan pokok yang dengannya dapat memecahkan masalah-masalah makna dan nilai, menempatkan tindakan atau suatu jalan hidup dalam konteks yang lebih luas, kaya, dan bermakna. Zohar dan marshal (dalam Siswanto dan Roekhan, 2015:133) menyatakan bahwa kecerdasan spiritual lebih merupakan sebuah konsep yang berhubungan dengan bagaimana seseorang cerdas dalam mengelola dan mendayagunakan makna-makna, nilai-nilai, dan kualitas-kualitas kehidupan spiritualnya. Kehidupan spiritual meliputi hasrat untuk bermakna (the will to meaning) yang memotivasi kehidupan seseorang untuk senantiasa mencari makna hidup (the meaning of life) dan mendambakan hidup bermakna (the meaningful life) (Mujib dan Mudzakir, 2001:324).

"Katakan pada hatimu bahwa takut menderita itu lebih buruk daripada menderita itu sendiri. Dan bahwa tidak ada hati yang pernah menderita saat ia mengejar mimpimimpinya, karena setiap detik dari pencarian itu adalah detik perjumpaan dengan Tuhan dan dengan keabadian." (halaman 139-140)

Novel Sang Alkemis ini mempengaruhi relung spiritul pembaca melalui nasehat Sang Alkemis kepada tokoh Santiago. Bahwasanya seseorang harus berani menderita untuk mengejar mimpinya. Karena setiap cobaan yang kita terima adalah detik perjumpaan dengan Tuhan dan keabadian. Bahwa mewujudkan mimpi adalah bagian dari 'jihat' menuju jalan kepada Tuhan. Hal ini memantabkan pembaca sastra bahwa kita tidak perlu takut menderita dalam meraih cita-cita karena ini merupakan salah satu jalan menuju Tuhan. 


\section{Karya Sastra sebagai Media Motivasi dan Inspirasi dalam Pendidikan}

Dalam pembentukan karakter, peserta didik membutuhkan teladan yang menginspirasi. Inspirasi dapat dibagikan melalui berbagai media dan cara dalam pendidikan karakter oleh pendidik. Membentuk karakter memerlukan proses inspirasi. Proses memberi inspirasi adalah sebuah proses persuasi karena di dalamnya ada usaha untuk mengubah sikap, perilaku, dan opini (tampubolon, 2014:516). Berkaitan dengan pengaruh karya sastra terhadap pembaca, novel Sang Alkemis ini dapat dijadikan sebagai salah satu alternatif sebagai media motivasi dan inspirasi dalam pendidikan. Hal ini disebabkan karena novel ini mampu memberikan pengaruh yang menimbulkan kesan yang mendalam, yang menghujam sanubari, yang akhirnya berdampak didaktis bagi dirinya (Endraswara, 2008:70). Novel ini mampu mengubah sikap, perilaku, dan opini pembaca untuk mewujudkan legenda pribadinya.

\section{Penutup}

Novel Sang Alkemis karya Paulo Coelho merupakan karya sastra yang mampu membangkitkan kekuatan terhadap pembacanya. Novel ini memberikan inspirasi dan motivasi yang dapat menggerakkan kekuatan terhadapa pembaca untuk memiliki mimpi dan bekerja keras untuk meraih mimpi. Hal ini merupakan daya lunak yang ditimbulkan karya sastra dalam mengubah pandangan yang mengubah pola pikir dan kiblat hidup seseorang. Daya lunak ini terepesentasi dalam dampak karya sastra yang mempengaruhi tehadap karakter, pendidikan dan spiritual pembaca. Disamping kaitannya dengan dunia pendidikan bahwasannya karya sastra dapat digunakan sebagai media motivasi dan inspirasi untuk memberikan ruh kepada siswa untuk memaknai hidup untuk menjadi lebih berarti.

\section{Daftar Rujukan}

Coelho, Paulo. Sang Alkemis. Terjemahan oleh Hamid Basyaib dan Yunita. 1999. Jakarta: Alvabet

Eagleton, Terry. 1996. Teori Sastra Sebuah Pengantar 
Komprehensif.Terjemahan Harfiyah Widiawati dan Evi Setyarini. 2010. Yogyakarta: Jalasutra

Endraswara, Suwardi. 2008. Metode Penelitian Psikologi Sastra Teori, Langkah dan Penerapannya. Yogyakarta: MedPress

Minderop, Albertine. 2016. Psikologi Sastra. Jakarta: Yayasan Pustaka Obor Indonesia

Ratna, Nyoman Kutha. 2012. Teori, Metode, dan Teknik Penelitian Sastra dari Strukturalisme hingga Postrukturalisme Perspektif Wacana Kritis. Yogyakarta: Pustaka Pelajar

Siswanto, Wahyudi dan Roekhan. 2015. Psikologi Sastra. Malang: Media Nusa Creative
Ula, Shoimatul. 2013. Revolusi Belajar Kecerdasan Optimalisasi Pembelajaran melalui Kecerdasan Majemuk. Yogyakarta: Ar-ruzz Media

Wulan, Nawang.2010. Mendengar Hati, Mengejar Mimpi dan Realitas Dunia: Interpretasi Simbol Dalam Novel The Alchemist Karya Paulo Coelho. Tesis tidak diterbitkan. Semarang: Program Pascasarjana Universitas Diponegoro. 